\title{
Bronze Age metal artefacts found on Cyprus - metal from Anatolia and the Western Mediterranean
}

\author{
Objetos metálicos de la Edad del Bronce de Chipre - metal procedente de Anatolia \\ y el Mediterráneo Occidental
}

\author{
Zofia A. Stos-Gale (*) \\ Noel H. Gale $(* *)$
}

\begin{abstract}
Hundreds of Bronze Age metal artefacts excavated on archaeological sites in Cyprus have been analysed for their lead isotope and elemental composition in the Isotrace Laboratory, University of Oxford, in the years 1982-2002. In parallel, but in particular after 1995, hundreds of samples of minerals and slags collected from the mines and smelting sites around the Troodos Mountains were also analysed. Most of the results were published in various articles over the years, but the interpretation of some of the lead isotope data needs a current revision in view of new research conducted in Spain, Sardinia and southern France. It has been known that the lead isotope data for metal artefacts from the Cypriot Bronze Age sites shows that not all of the copper is consistent with origin from the Cypriot ores. In addition, the lead and silver artefacts found there must have been imported, because there are no lead or silver ores on Cyprus. The re-evaluation of the data shows that about $11 \%$ of the analysed metal artefacts are consistent with the origin from the deposits in the Aegean and Turkey, while about $14 \%$ with sources in the Western Mediterranean. This paper discusses in detail the current interpretation of the research into the sources of imported metal found in the Bronze Age context on Cyprus.
\end{abstract}

\section{RESUMEN}

Cientos de objetos de metal de la Edad del Bronce excavados en yacimientos de Chipre han sido analizados para conocer su composición elemental y sus isótopos de plomo en el Isotrace Laboratory de la Universidad de Oxford entre los años 1982 y 2002. Especialmente con

$(*)$ Ifold, West Sussex. Correo electrónico: sophie@stos-gale.com

$(* *)$ Nuffield College, University of Oxford.

Recibido: 15-III-2010; aceptado: 26-IV-2010. posterioridad a 1995 cientos de muestras de minerales y escorias recogidas de minas y sitios de reducción de minerales localizadas en el entorno de las montañas de Troodos también fueron analizadas. La mayoría de los resultados fueron publicados en varios artículos a lo largo del tiempo, pero la interpretación de algunos análisis de isótopos de plomo necesitan de una revisión a la vista de las nuevas investigaciones realizadas en España, Cerdeña y Sur de Francia. Es sabido que los datos de isótopos de plomo de objetos metálicos de yacimientos chipriotas de la Edad del Bronce muestran que no todo el cobre es consistente con un origen de minerales de Chipre. Además, los objetos de plomo y plata debieron ser importados debido a que no existen minerales de plomo o plata en la isla. La re-evaluación de los datos muestra que alrededor del $11 \%$ de los objetos de metal analizados son consistentes con un origen en los depósitos del Egeo y Turquía, mientras que un $14 \%$ lo son con minerales del Mediterráneo Occidental. Este artículo discute en detalle la interpretación actual de la investigación sobre el metal importado recuperado en contextos de la Edad del Bronce en Chipre.

Key words: Cyprus in the Bronze Age; Contacts in the BA Mediterranean; Metal trade; Lead isotope provenance studies.

Palabras clave: Chipre en la Edad del Bronce; Contactos mediterráneos en la Edad del Bronce; Comercio de metal; Estudios de procedencia con isótopos de plomo.

\section{INTRODUCTION}

Cyprus is often quoted in the archaeological literature as the most important producer of copper in the Bronze Age Mediterranean (but see Muhly 1991). However, in contrast with Bronze 
Age Mediterranean pottery, it is not possible to identify copper from Cyprus amongst the archaeological finds by their appearance or chemical composition. It is also not necessarily possible to identify by eye metal that might have been brought to Cyprus from other parts of the world, since it may have been used to make artefacts in the local Cypriot style.

The lead isotope analysis of metals can provide a scientific tool for such identification, providing that the lead isotope characteristics of Cypriot ores are well established. To provide the background knowledge for lead isotope provenance studies of the Bronze Age Mediterranean metals, over 500 ores and slags collected on Cyprus and 375 copper, lead and silver artefacts from Cypriot Bronze Age sites were analysed between 1975-2002 in the Oxford Isotrace Laboratory (Stos-Gale and Gale 2009). Many papers have been published on this topic, notably in 1994 the results as they were known then (Stos-Gale and Gale), followed later by new data for the ores (Stos-Gale et al. 1997; Gale et al. 1997) and slags (Stos-Gale et al. 1998). Much time was also devoted to the analysis and interpretation of the lead isotope data for copper oxhide ingots (e.g. Gale 1999). Unfortunately, when the data for the Cypriot Bronze Age artefacts and their interpretation were published in 1994, there were only 32 analyses of ores from Cyprus. Since the main body of ore data was published in 1997 and 1998 this interpretation has not hitherto been re-examined in the light of the later analyses of ores and slags.

Additionally, after the 1994 paper was submitted for publication new evidence emerged for the mining of copper, lead, silver and tin ores in the Bronze Age in the Taurus Mountains in Southern Turkey (Yener et al. 1991; Hirao et al. 1995). Only a small group (112) of lead isotope analyses so far were published for the large area of the Taurus Mountains, but even with this small group of data, their lead isotope ratios are distinctive enough to reveal the presence of metals from this region in the Aegean from the Early Bronze Age (EBA) to the Late Bronze Age (LBA). For example, copper tools and weapons, and silver fragments found on the Uluburun shipwreck originate largely from the copper and lead ores mined in the Taurus, even though none of the copper oxhide ingots on this ship are made of Taurus copper (Gale and Stos-Gale 2005).
Further, since 1995 systematic lead isotope analyses of ores from Sardinia and Spain (for example: Stos-Gale et al. 1995; Santos et al. 2004; Montero-Ruiz et al. 2006 and 2009; Klein et al. 2009) added considerably to the data available for comparative interpretation. An increased number of archaeometallurgical surveys and lead isotope analyses of lead-silver and copper ores from the south of France (Brevart et al. 1982; Le Guen et al. 1991; Baron et al. 2006) also brought a possibility of further comparisons.

The comparisons of the lead isotope data for copper-based artefacts from the Cypriot Bronze Age sites showed not only that not all of them were consistent with origin from the Cypriot ores, but also that the imports were not only from the metal sources located in the Aegean and the Near East. This paper will concentrate on discussion of the possible origin of these non-Cypriot metal artefacts in view of the currently known lead isotope compositions of ores from Anatolia and the western Mediterranean, as a contribution to the discussion of the exchange and trade of raw materials and objects across the Mediterranean in the Bronze Age.

\section{THE ARCHAEOLOGIST'S VIEW OF THE LONG DISTANCE TRADE IN THE MEDITERRANEAN IN 3000 - 1000 BC}

In his key lecture at the conference "Between the Aegean and Baltic Seas" Joseph Maran (2007) argued convincingly that: "...the traits usually cited as evidence for the cultural unity of the Mediterranean are the outcome of a multi-layered spatial process brought about by the gradual expansion of interconnections between the societies. We can be fairly certain that in the early $1^{\text {st }}$ millennium $B C$ at the latest some sort of geographical concept of the Mediterranean must have existed." The archaeological evidence based on the pottery and metal finds proves that these interconnections existed at least a millennium or more previously, for example in Sicily, southern Italy and Sardinia there are finds of LHI pottery, possibly as early as 1600 BC (see: Giardino 1992 and 2000). The contacts between people inhabiting the area surrounding the Mediterranean Sea were certainly enhanced in the Late Bronze Age due to the improvements in boat building. The famous 
Uluburun shipwreck that sunk off the south-east coast of Turkey around 1317 BC proves how much cargo such comparatively small ships could carry: ten tons of copper, one ton of tin, hundreds of pieces of pottery, glass ingots and many other items (Bass 1987; Pulak 1998, 2001 and 2005). At the end of the $2^{\text {nd }}$ millennium $\mathrm{BC}$ a considerable quantity of copper from Cyprus reached Sardinia in the shape of oxhide ingots (Stos-Gale and Gale 1992; Gale 1999; Kassianidou 2001), so it seems most likely that at that time ships similar to Uluburun might have been sailing across the whole width of the Mediterranean Sea. However, the movement of goods along the coast must have started much earlier. For example, some finds in the Peloponnese suggest connections between the western Bell Beaker phenomenon and the Aegean already in the $3^{\text {rd }}$ Millennium BC, the Aegean Early Bronze Age (Heyd 2007, p. 100). Such early contacts are also argued very persuasively by Maran (2007, pp. 5-8).

The archaeologist's view of contacts between prehistoric peoples and cultures is based on studies of similarities of pottery, architecture, shapes of tools and weapons and burial customs. The lead isotope analyses of metal artefacts from archaeological sites provide a new tool for studying such interconnections. The identification of copper ingot fragments from Sardinian nuragi as metal from Cyprus was a typical example of its use. The Oxford lead isotope database (OXALID) holds lead isotope data for over 4,500 Bronze Age metal artefacts (Stos-Gale and Gale 2009). The lead isotope compositions of the artefacts from Greece, Cyprus and the Near East match mainly the characteristics of ore deposits from the Eastern Mediterranean including the Aegean (Stos-Gale 2000). However, amongst the Helladic, Minoan and Cypriot metals there are objects that have lead isotope ratios that are not found amongst the surveyed Aegean, Anatolian, Balkan and Near Eastern mineral deposits. The recent publications of many new lead isotope data for the ores from France, Italy and Spain give an opportunity to re-examine these data.

\section{INTERPRETATION OF LEAD ISOTOPE DATA}

Lead isotope provenance studies can lead to the correct answers only in conjunction with archaeometallurgical surveys of ore deposits and ancient slag heaps, because the interpretation of lead isotope data for provenance studies of ancient artefacts is based not only on numerical comparisons, but also on the knowledge of the geochemistry of ore deposits and the history of their exploitation. The chief ore deposits around the Mediterranean are well known and recorded in the geological literature. Many of them have been surveyed by archaeometallurgists and there is some evidence for the dating of the ancient activities. Many have been characterised isotopically, at least to a certain degree. Some lead isotope data published in the geological journals also can be used. The available information has been entered on a database of lead isotope compositions relevant to the research into Bronze Age Mediterranean trade in metals and was used for the purpose of this paper (OXALID - StosGale and Gale 2009). The main references to lead isotope data published until 2009 are given in table 1.

The interpretation of the lead isotope data of ancient artefacts includes several steps:

1. Comparison of all three lead isotope (LI) ratios: ${ }^{208} \mathrm{~Pb} / 206 \mathrm{~Pb},{ }^{207} \mathrm{~Pb} / 206 \mathrm{~Pb}$ and ${ }^{206} \mathrm{~Pb} / 204 \mathrm{~Pb}$, measured for the samples of each artefact with all available ore data using TestEuclid (see Stos-Gale and Gale 2009), and identification of ore data identical within $\pm 1 \sigma$ with the data for the each artefact to identify possible sources of the ore.

2. Consideration of the geochemistry and archaeometallurgy of identified ore deposits.

3. Construction of two mirror image LI plots of the ores and the artefacts; that means two plots per page for both of which the $\mathrm{X}$-axis is ${ }^{207} \mathrm{~Pb} / 206 \mathrm{~Pb}$, and $\mathrm{Y}$-axis is ${ }^{208} \mathrm{~Pb} /{ }^{206} \mathrm{~Pb}$ for the upper diagram and $206 \mathrm{~Pb} / 204 \mathrm{~Pb}$ for the lower diagram. Consistent use of the same pairs of plots makes it easier to see the emerging patterns.

4. Graphic and numerical comparisons with other artefacts from the chronologically and geographically relevant sites (optional)

5. Assessment of the possibility of "mixed" origin: the metal produced from melting together two or more pieces of metal originating from different sources will show lead isotope composition plotting on the line joining the ores from these sources, or between the sources if more than two were used.

Large number of lead isotope data of ores that is currently used for comparisons is far too com- 


\begin{tabular}{|c|c|c|}
\hline Country or Region & $\begin{array}{l}\text { Number of } \\
\text { published LI } \\
\text { analyses }\end{array}$ & References \\
\hline Turkey & 307 & $\begin{array}{l}\text { Wagner et al. } 1985 \text { 1986a 1989; Pernicka et al. 1984, Seeliger et al. } \\
\text { 1985, Yener et al. 1991, Hirao et al. } 1995\end{array}$ \\
\hline The Near and Middle East & 258 & Hauptmann et al. 1992, Stos-Gale and Gale 1980, Stacey et al. 1980 \\
\hline Tunisia & 94 & Skaggs 2009 \\
\hline The Balkans & 450 & Pernicka et al. 1993, Stos-Gale et al. 1998a \\
\hline Cyprus & 455 & Gale et al. 1997 \\
\hline Greece & 875 & Stos-Gale et al. 1996, Wagner et al. 1986b \\
\hline Mainland Italy & 76 & Stos-Gale et al. 1995 \\
\hline Sardinia & 378 & Stos-Gale et al. 1995, Begemann et al. 2001 \\
\hline Southern France & 181 & Baron et al. 2006, Brevart et al. 1982, Le Guen et al. 1991 \\
\hline Spain & 437 & $\begin{array}{l}\text { Arribas and Tosdal 1994, Stos-Gale et al. 1995, Hunt-Ortiz 2003, Santos } \\
\text { et al. } 2004 \text {, Montero Ruiz et al. 2009a\&b, Klein et al. 2009, Renzi et } \\
\text { al. } 2009\end{array}$ \\
\hline
\end{tabular}

Tab. 1. Published lead isotope data on ore and slag samples available for comparisons with the Mediterranean Bronze Age artefacts and the number of data on the OXALID database.

plex for visual identification of origin of ancient materials. Three-dimensional plots become very complex and virtually incomprehensible when large number of data is plotted, therefore it is not really possible to compare visually all ore sources on one diagram. Very large scale plots, for example presenting the ${ }^{208} \mathrm{~Pb} / 206 \mathrm{~Pb}$ range of values from 2.04 to 2.12 , obscure the details of the data. Therefore, the most reliable way of interpreting the data is to use the Euclidean distances for selecting the possible ores sources, and then making the detail plots of data selected on this basis.

In the context of this paper it needs to be said, that the identification of the origin of copper from a distant source in a Bronze Age Eastern Mediterranean artefact does not necessarily mean that the artefact was not made in the area where it was excavated. The authors of this paper believe, and argued earlier on several occasions, that the reuse of metal in the Bronze Age Mediterranean was mostly by melting small amounts of metal to make another small object, or a few objects, and mostly did not involve mixing together metal derived from different ore sources. The melting of metal in settlements was restricted to small crucibles, as proved by many such items found on sites in Crete and Mainland Greece (for example on Crete: Palaikastro, Ayia Photia, Myrtos-Pyrgos, Chania; on the Mainland: Ayios Stephanos, Nichoria). The lead isotope compositions of metal artefacts found on the same site, or in the same region reflect this practice (Stos-Gale 2000, p. 58). Conversely, the stylistic features of an artefact do not necessarily identify the source of metal, for example an appropriate size artefact from Anatolia that arrive in Cyprus might have been melted and a typically Cypriot dagger made.

\section{COPPER BASED ARTEFACTS ON CYPRUS OF NON-CYPRIOT ORIGIN - METAL FROM THE NEAREST NEIGHBOURS}

Cypriot ores are predominantly copper and iron sulphides, also oxidised ores of iron, manganese and copper. Particular geological spreading "axes" contain ores from the same ore forming events (Stos-Gale et al. 1997). There are no ore deposits of tin or lead on this island. The only metals produced on Cyprus in antiquity were copper and perhaps iron. The major data base of lead isotope compositions of Cypriot ores was published in 1997 (Gale et al. 1997a). The smelting of Cypriot copper ores in different periods is documented by numerous copper slag heaps scattered on the island (Stos-Gale et al. 1998b) and many finds of slags in Bronze Age (BA) and later archaeological sites, for example in Enkomi, Kalavasos-Ayios Dhimitrios and Kition. Lead isotope plots of these data have been published in numerous papers, for example: Gale 1999 (Fig. 8). Amongst other Bronze Age metal artefacts analysed in the Isotrace Laboratory in Oxford we have analysed 375 from Cyprus dated from the Early (EC: 2400-1900 BC), Middle 
(MC: 1900-1625 BC) and Late Cypriot (LC: 1625-1050 BC) periods, covering a time span of about 1400 years.

Comparison on two mirror LI diagrams of all analysed artefacts from the Cypriot Bronze Age sites with the ores and slags shows clearly that the great majority of the copper artefacts was indeed made from copper originating from Cypriot deposits (Fig. 1). However, it is also clear that some metals; not only lead and silver (as expected), but also copper, have been brought to Cyprus from across the sea (groups A and B). A very general description of these groups in terms of the ore formations would be to say that Group A falls within the region of the lead isotope diagram that represents ores geologically younger than Cypriot ores, while Group B represents ore
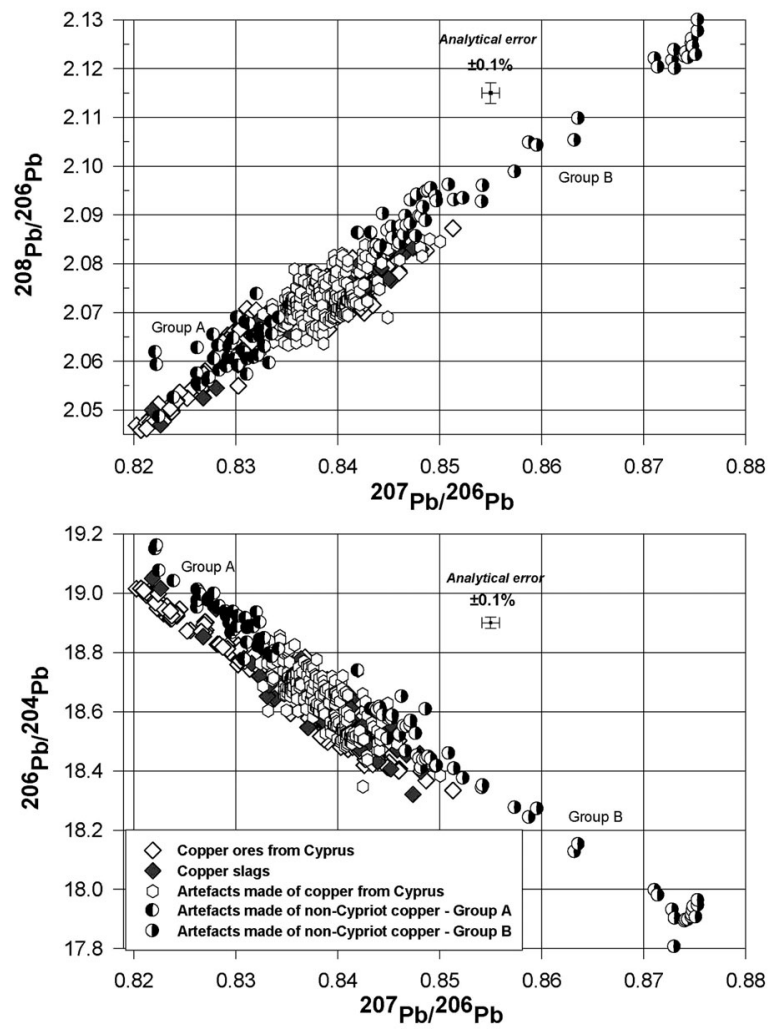

Fig. 1. Two mirror plots of lead isotope ratios measured for the ores and slags from Cyprus compared with the values measured for the metal artefacts from Cypriot Bronze Age sites. Groups A and B represent metals of non-Cypriot origin and include copper based alloys, silver and lead. Group A consists of metals that originated from southern Turkey and Aegean, Group B of metals from the western Mediterranean. deposits of older age. These two isotopic groups could not have been a result of mixing metals from geographically different sources with Cypriot copper. The lead isotope composition of any metal produced from two, or more, pieces of different origin will show lead isotope compositions falling between the data points for original sources. In this case these two "foreign" groups are of lower (Group A) and higher (Group B) ${ }^{208} \mathrm{~Pb} / 206 \mathrm{~Pb}$ and ${ }^{207} \mathrm{~Pb} / 204 \mathrm{~Pb}$ ratios than the Cypriot ores, so these artefacts must originate from isotopically different ores (see for example: Stos 2009, pp. 168-169 and Fig. 2).

Group A consists of 44 artefacts that include copper-based objects, lead and silver covering all chronological periods of the Cypriot Bronze Age (Tabs. 2 and 3). Twenty-four copper and lead
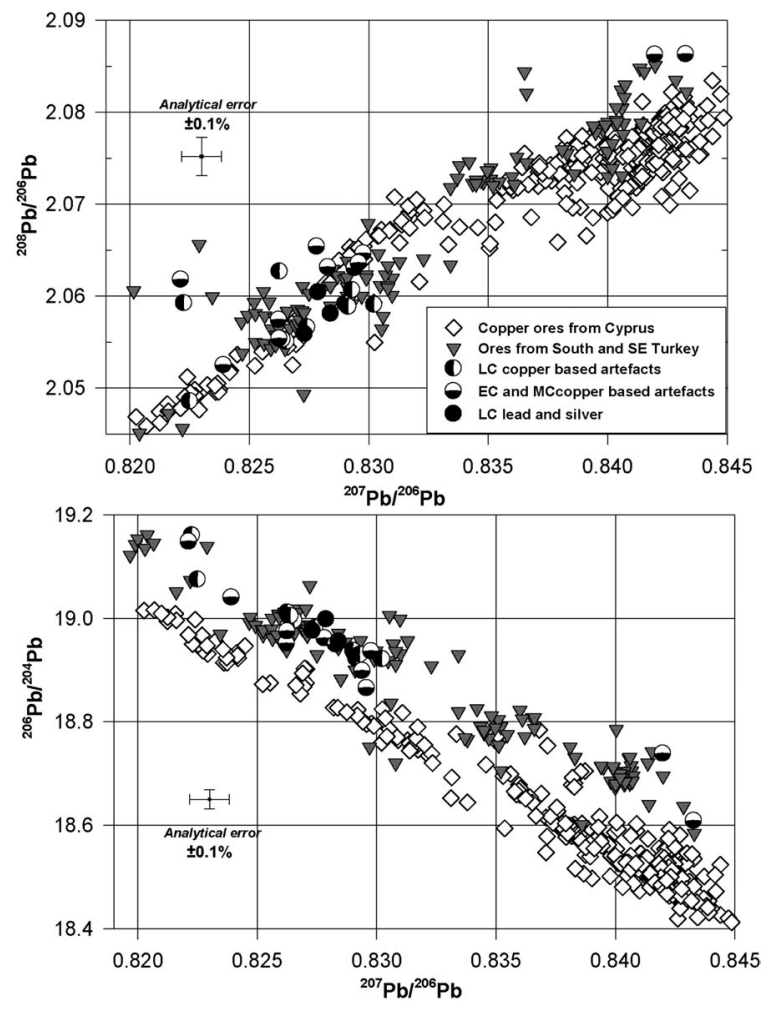

Fig. 2. Enlarged area of Figure 1 showing in detail the data points for Group A consistent with the ores from Southern Turkey. For clarity of the drawing the artefacts from Group A consistent with the Aegean origin are not plotted on this diagram. If included, the ores from the mines of Lavrion, Kythnos and Seriphos would plot in the area below the Cypriot ores on the upper diagram and above the Turkish ores on the lower diagram starting from ${ }^{207} \mathrm{~Pb} /{ }^{206} \mathrm{~Pb}$ values of about 0.83 . 
i. South-east region of Elazig including the Ergani Maden mines

\begin{tabular}{|c|c|c|c|c|c|}
\hline Region or site & Object & Dated to & ${ }^{208} \mathrm{~Pb} /{ }^{206} \mathrm{~Pb}$ & ${ }^{207} \mathrm{~Pb} /{ }^{206} \mathrm{~Pb}$ & ${ }^{206} \mathrm{~Pb} /{ }^{204} \mathrm{~Pb}$ \\
\hline Unprovenanced, 74/6/6 & Copper knife, 10 (1) & EC - Philia Culture & 2.06358 & 0.82959 & 18.865 \\
\hline Lapithos & $\begin{array}{l}\text { Arsenical copper dagger } \\
\text { 702: } 132(2)\end{array}$ & MC 3 & 2.06539 & 0.82783 & 18.961 \\
\hline $\begin{array}{l}\text { From Karpass, bought, Ash- } \\
\text { molean Museum }\end{array}$ & $\begin{array}{l}\text { Copper eyelet pin } 1953 . \\
1302(3)\end{array}$ & MC 3? & 2.06178 & 0.82214 & 19.148 \\
\hline Ay. Iakovos & Copper tweezers 10 A14 & $\mathrm{LC} 1 \mathrm{~A}$ & 2.06267 & 0.82627 & 19.011 \\
\hline Katydhata & $\begin{array}{l}\text { Fragment of a tin bronze pin } \\
\text { Nicosia Museum, no No. }\end{array}$ & $\mathrm{LC}$ & 2.05905 & 0.83023 & 18.921 \\
\hline
\end{tabular}

ii. Taurus Mountains, southern Turkey

\begin{tabular}{|c|c|c|c|c|c|}
\hline Region or site & Object & Dated to & ${ }^{208} \mathrm{~Pb} /{ }^{206} \mathrm{~Pb}$ & ${ }^{207} \mathrm{~Pb} /{ }^{206} \mathrm{~Pb}$ & ${ }^{206} \mathrm{~Pb} /{ }^{204} \mathrm{~Pb}$ \\
\hline Vasilia & Copper bracelet, 1957.24 (2) & EC - Philia Culture & 2.06304 & 0.82941 & 18.898 \\
\hline Unprovenanced, 74/6/4 & $\begin{array}{l}\text { Tin bronze poker-butt spear } \\
\text { head, } 4 \text { (1) }\end{array}$ & EC - Philia & 2.06313 & 0.82830 & 18.949 \\
\hline Unprovenanced, $74 / 6 / 5$ & Tin bronze sword, 8 (1) & EC - Philia & 2.05537 & 0.82626 & 18.974 \\
\hline Lapithos & $\begin{array}{l}\text { Arsenical copper sword, } \\
\text { "rat-tang", 313:B89 }\end{array}$ & EC 3-MC 1 & 2.06463 & 0.82978 & 18.936 \\
\hline Lapithos & $\begin{array}{l}\text { Arsenical copper axe, } \\
\quad 702: 131(2)\end{array}$ & MC 3 & 2.05742 & 0.82624 & 18.951 \\
\hline Lapithos & Tin bronze pin, 315:A55a & MC 2 & 2.08626 & 0.84199 & 738 \\
\hline Lapithos & Tin bronze pin $315: \mathrm{A} 81$ & $\mathrm{MC2}$ & 2.08630 & 0.84328 & 18.608 \\
\hline Nitovikla & $\begin{array}{l}\text { Arsenical copper pin, NIT } \\
\text { GR. } 2.58 \mathrm{~B}\end{array}$ & MC 3/LC 1 & 2.05249 & 0.82393 & 19.040 \\
\hline Ay. Iakovos & Copper blade, 8:60 & LC $1 \mathrm{~A}$ & 2.04856 & 0.82251 & 19.075 \\
\hline Ay. Iakovos & $\begin{array}{l}\text { Tin bronze spear butt, AY IAK } \\
\text { BAS } 43\end{array}$ & LC? & 2.05915 & 0.82902 & 18.937 \\
\hline Kalavasos, Ay. Dhimitrios & $\begin{array}{l}\text { Tin bronze fragments KAD15 } \\
(80-T .5-3.1)\end{array}$ & LC 2C? & 2.05659 & 0.82743 & 18.981 \\
\hline Kalavasos, Ay. Dhimitrios & $\begin{array}{l}\text { Copper bowl KAD207a } \\
(80-A 50-3.1)\end{array}$ & LC $2 \mathrm{C} ?$ & 2.06065 & 0.82931 & 18.929 \\
\hline Enkomi & $\begin{array}{l}\text { Bronze statue G, Enkomi 1960, } \\
\text { No. } 126\end{array}$ & LBA (Mycenaean) & 2.05504 & 0.82656 & 18.995 \\
\hline Maroni & Bronze dagger 3198.108 (3) & $\mathrm{LC}$ & 2.05923 & 0.82227 & 19.160 \\
\hline Hala Sultan Tekke & $\begin{array}{l}\text { Copper fragment F1552 } \\
\text { (1980)a (4) }\end{array}$ & LC $3 \mathrm{~A}$ & 2.05884 & 0.82915 & 18.922 \\
\hline Hala Sultan Tekke & $\begin{array}{l}\text { Copper fragment F1552 } \\
\text { (1980)b (4) }\end{array}$ & LC 3A & 2.05526 & 0.82640 & 19.004 \\
\hline Hala Sultan Tekke & $\begin{array}{l}\text { Irregular piece of lead } \\
\text { N1210(4) }\end{array}$ & LC 3A & 2.06041 & 0.82789 & 18.998 \\
\hline Hala Sultan Tekke & Lump of lead N1424 (4) & LC 3A & 2.05808 & 0.82841 & 18.955 \\
\hline Hala Sultan Tekke & Lump of lead N1432 & LC $3 \mathrm{~A}$ & 2.05587 & 0.82732 & 18.975 \\
\hline
\end{tabular}

Tab. 2. Artefacts from Cypriot BA sites made of copper consistent with origin from the ores in the south-east and south Turkey.

(1) Published in Webb et al. 2006.

(2) Published in Stos-Gale and Gale 1994, p. 212.

(3) Published in Stos-Gale and Gale 1994, p. 213.

(4) Published in Stos-Gale and Gale 1994, p. 214

T. P., 67, N. ${ }^{\circ} 2$, julio-diciembre 2010, pp. 389-403, ISSN: 0082-5638 doi: $10.3989 /$ tp.2010.10046 
i. Consistent with the copper ores from the Cyclades (Kythnos and Seriphos)

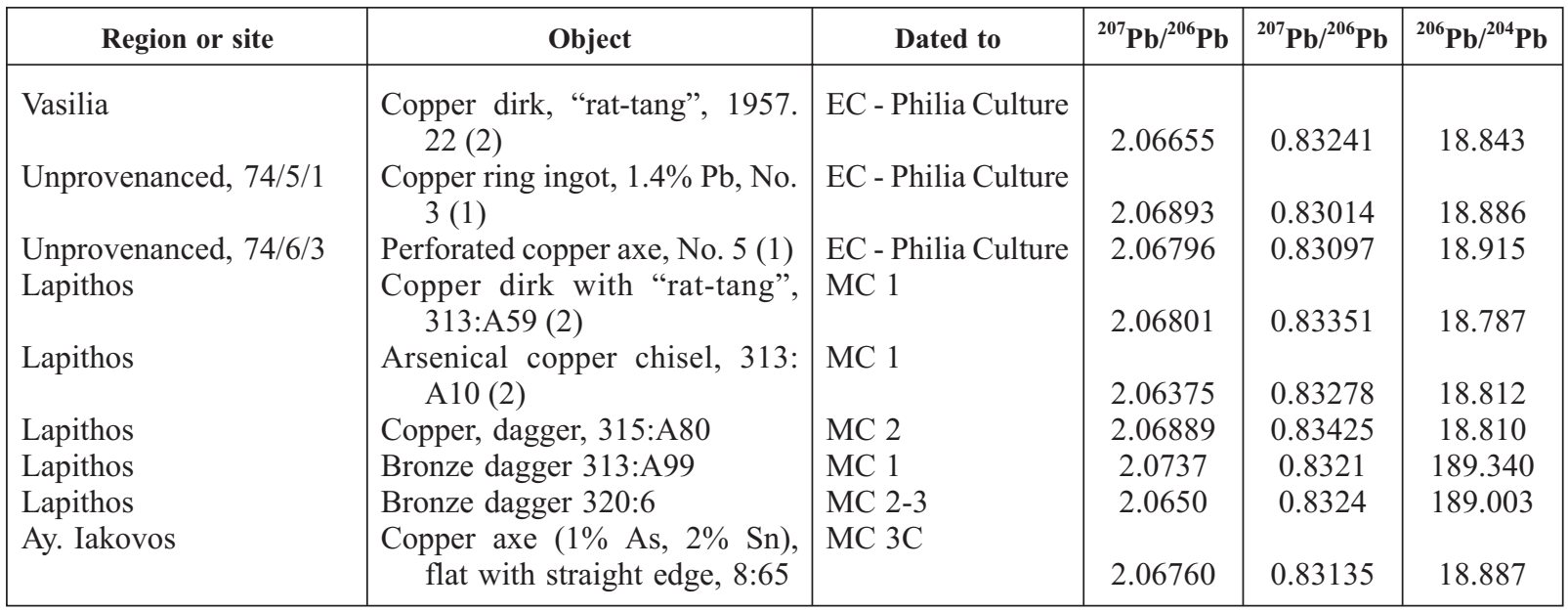

ii. Consistent with the origin from the ores occurring in Lavrion.

\begin{tabular}{|c|c|c|c|c|c|}
\hline Region or site & Object & Dated to & ${ }^{208} \mathrm{~Pb} /{ }^{206} \mathrm{~Pb}$ & ${ }^{207} \mathrm{~Pb} /{ }^{206} \mathrm{~Pb}$ & ${ }^{206} \mathrm{~Pb} /{ }^{204} \mathrm{~Pb}$ \\
\hline Vasilia & $\begin{array}{l}\text { Copper dagger, T. 1, } 1957 . \\
21(2)\end{array}$ & EC - Philia Culture & 2.05959 & 0.83331 & 18.795 \\
\hline Vounous & $\begin{array}{l}\text { Copper dagger, "rat-tang", } \\
\text { T.15, 15:73 (2) }\end{array}$ & EC 3B & 2.05722 & 0.83112 & 18.832 \\
\hline Lapithos & Copper pin 309:A52b & $\mathrm{EC} 3 \mathrm{~B}-\mathrm{MC} 1$ & 2.06070 & 0.83177 & 18.885 \\
\hline Alambra & Lead ring A $1026(5)$ & MC 1 & 2.06118 & 0.83223 & 18.82 \\
\hline Lapithos & $\begin{array}{l}\text { Arsenical copper dagger } 320 \text { : } \\
\quad 6(2)\end{array}$ & MC 2-3 & 2.06168 & 0.83087 & 18.775 \\
\hline Pyla Kokkinokremos & $\begin{array}{l}\text { Silver bowl, hemispherical, } \\
\text { 1982:112b (3) }\end{array}$ & LC $2 \mathrm{C}$ & 2.06033 & 0.82988 & 18.875 \\
\hline Pyla Kokkinokremos & Silver ingot $1982: 113 \mathrm{a}(3)$ & $\mathrm{LC} 2 \mathrm{C}$ & 2.0662 & 0.83277 & 18.831 \\
\hline Pyla Kokkinokremos & Silver fragment $1982: 114 \mathrm{a}(3)$ & $\mathrm{LC} 2 \mathrm{C}$ & 2.0655 & 0.83358 & 18.784 \\
\hline Kalavasos, Ay. Dhimitrios & Lump of tin bronze KAD11 (3) & LC $2 \mathrm{C}$ & 2.06297 & 0.83284 & 18.847 \\
\hline Ayios Iakovos & $\begin{array}{l}\text { Tin bronze spear butt AY IAK } \\
\text { BAS } 48\end{array}$ & LC & 2.06044 & 0.83116 & 18.882 \\
\hline Lapithos & $\begin{array}{l}\text { Fragment of a flat spiral silver } \\
\text { ring 322:A9 }\end{array}$ & $\mathrm{LC}$ & 2.06497 & 0.83170 & 18.889 \\
\hline
\end{tabular}

Tab. 3. Artefacts from Cypriot BA sites consistent with the origin from the Aegean copper sources.

artefacts falling into the Group A are consistent with the origin from the lead, silver and copper ore deposits in the present day Turkey. Of these 19 are consistent with the origin from the Taurus Mountains in southern Turkey (Yener et al. 1991) and five from copper deposits in the area of Elazig-Malatya in the south eastern part of that country. The famous ancient copper mines of

(5) Published in Gale et al. 1997b.
Keban and Ergani Maden (Seeliger et al. 1985; Wagner et al. 1986b) are located in this latter region. The Taurus Mountains are directly north of the coast of mainland Turkey facing Cyprus and the sailing distance to northern Cyprus is about $100 \mathrm{~km}$. Similar distance is from the end of the Cypriot Karpass Peninsula to the coast near Adana, where a trade route from Elazig-Malatya reaches the Mediterranean coast. These two mining regions, Taurus and Elazig-Malatya are the geographically nearest to Cyprus metal sources. 
Descriptions of the objects consistent with the origin from these Anatolian mines and their lead isotope data are listed in table 2. On figure 2 the data for these 24 artefacts are plotted together with the data for the Cypriot and Turkish ores, showing a particularly good consistency with the data for Turkish ores on the lower part of the plot for the isotope ratios of ${ }^{206} \mathrm{~Pb} / 204 \mathrm{~Pb}$.

It is worth mentioning that a copper knife from the Philia Culture has a lead isotope composition consistent with the Ergani Maden mines, while a copper bracelet from the EC tombs in Vasilia and a tin bronze spearhead and a sword from a collection in Australia described by Webb et al. (2006) show lead isotope ratios consistent with the minerals from the Bolkardag region in the Taurus Mountains. These artefacts belong to the earliest group of metals found on Cypriot sites. These results indicate that some copper from Anatolia were coming to Cyprus in the second half of the $3^{\text {rd }}$ millennium BC. Only five amongst the analysed 375 artefacts show lead isotope ratios characteristic for the mines of the Elazig-Malatya region, their dates span the whole of the Bronze Age. The remaining 19 metal artefacts are consistent with ores located in the large area of the Taurus Mountains. Three of them are LC pieces of lead from Hala Sultan Tekke, the other artefacts include two MC tin bronze pins from the tombs in Lapithos and other $\mathrm{MC}$ and LC copper and bronze artefacts.

Another twenty artefacts falling into the non-Cypriot Group A are consistent with originating from the Aegean lead, silver or copper ore sources. The contacts between Cyprus and the Minoan and Mycenean cultures of the Aegean are well attested by finds of pottery and it is not surprising to see that some metal from the sources used in the Aegean was also reaching Cyprus. Lead isotope analyses of hundreds of Aegean Bronze Age metal artefacts show that the most prominent source of copper, lead and silver there from the early Bronze Age onwards were the large multimetallic deposits on the Lavrion peninsula in Attica (Gale et al. 2009). In the Early Bronze Age the Cycladic islands of Kythnos, Siphnos and Seriphos also played an important role as sources of metal (Stos-Gale 2000, pp. 6166, Figs. 3.3-3.5; Gale and Stos-Gale 2008a).

Nine objects are consistent with the lead isotope ratios characteristic for the copper smelted on the Cycladic islands of Kythnos and Seriphos
(Tab. 3.i). Both of these islands have provided some copper in the late $3^{\text {rd }}$ and early second millennium BC not only for the Aegean islands, but also for the Minoans and the Mainland Greece (see for example: Gale and Stos-Gale 2008a), so the metal from these ore sources circulated in the earlier periods of the Bronze Age in the eastern Mediterranean together with lead and silver from Siphnos (Gale and Stos-Gale 1981).

Eleven artefacts are fully consistent with the characteristic lead isotope compositions of the minerals in the mines of Lavrion on the southeast coast of Attica (Tab. 3.ii). One of these is a rare lead ring from MC 1 settlement of Alambra. The four LC silver objects consistent with the origin from Lavrion consist of a spiral ring from a tomb in Lapithos and three silver artefacts from Pyla Kokkinokremos (Karageorghis, Gale and Stos-Gale 1983). Lead isotope analyses of Bronze Age metal artefacts from Mainland Greece and Crete demonstrated that the Lavrion mines were intensively exploited since the Early Bronze Age (Gale et al. 2008b; 2009).

\section{METALS FROM THE WESTERN MEDITERRANEAN}

Great majority of presently analysed for their lead isotope composition ore deposits in the Eastern Mediterranean belong to geologically younger formations, not much earlier than $100 \mathrm{ma}$, and therefore their ${ }^{208} \mathrm{~Pb} / 206 \mathrm{~Pb}$ ratios are below the value of 2.09. The well known exceptions are the copper ores from the Arabah Valley that were exploited in the Bronze Age (Hauptmann et al. 1993). On the other hand, many of the Western Mediterranean ores are geologically older and their ${ }^{208} \mathrm{~Pb} /{ }^{206} \mathrm{~Pb}$ ratios are higher than 2.09 .

The lead isotope compositions of the 53 artefacts falling into the Group B represent the range of lead isotope ratios that have not been found amongst any of the ores in the eastern Mediterranean and the Near East (including the Arabah Valley ores). Some of the lead pieces from the Late Cypriot sites of Hala Sultan Tekke and Maa Paleokastro were identified already in 1994 as originating from the deposits on Sardinia (Stos-Gale and Gale 1994, pp. 213-214). However, there were other metals from Cypriot sites, in particular from the earlier periods, that did not 
show lead isotope consistency with any of the then isotopically characterised ore deposits.

The most surprising possibility came to light when re-examining these lead isotope data in the light of the recent publications of the lead isotope composition of ores from Bronze Age mines in the southern part of Massif Central in southern France. Conventional archaeological evidence of contacts between the Mediterranean coast of France and the Eastern Mediterranean is very weak if not non-existent. There are some possibilities that sherds belonging to the Beaker culture were found in Mainland Greece (Heyd 2007, p. 100), but we are not aware that anything like that was found on Cyprus. However, 26 Cypriot artefacts dated to EC3-MC3 period (2000 - 1625 $\mathrm{BC}$ ) and four dated to MC3-LC3 (1625-1050 BC) are fully consistent with the lead isotope data for ores from the Cevennes - Montaigne NoirHerault region of the Massif Central, the area west of Marseilles, directly north of the road leading from Narbonne, through Beziers and Montpellier to Nimes along the Mediterranean coast. The ore deposits of the Massif Central contain lead, silver and copper ores and are known to have been exploited from the end of the $3^{\text {rd }}$ millennium BC (Ambert 1995). Figure 3 represents comparison of the currently published lead isotope data for ores from the Massif Central with this group of artefacts which are listed in table 4.

The earliest objects apparently consistent with the origin of metal from the mines in the Massif Central are 13 lead rings from the tombs at Lapithos and Ayia Paraskevi dated to EC3-MC1 (1925-1800 BC). It is worth noting that lead was in use in Southern France since $3^{\text {rd }}$ millennium BC (Gurthez et al. 2005), but not in Spain (Delibes and Montero 1999) (6). From the same period comes a tin bronze awl from a tomb in Lapithos. Another tin bronze, tweezers, and two copper rings from Alambra are dated to the MC1. The presence of tin in these small objects is of interest, since it is usually assumed that tin was coming to the eastern Mediterranean from the Middle East, not the West.

From a slightly later period (MC2-MC3) there are five tin bronze pins from the tombs in Lapithos and one from the tomb in Leondari Vouno. From the same period are also two tin

(6) We are grateful for this reference to the one of the referees of this paper.
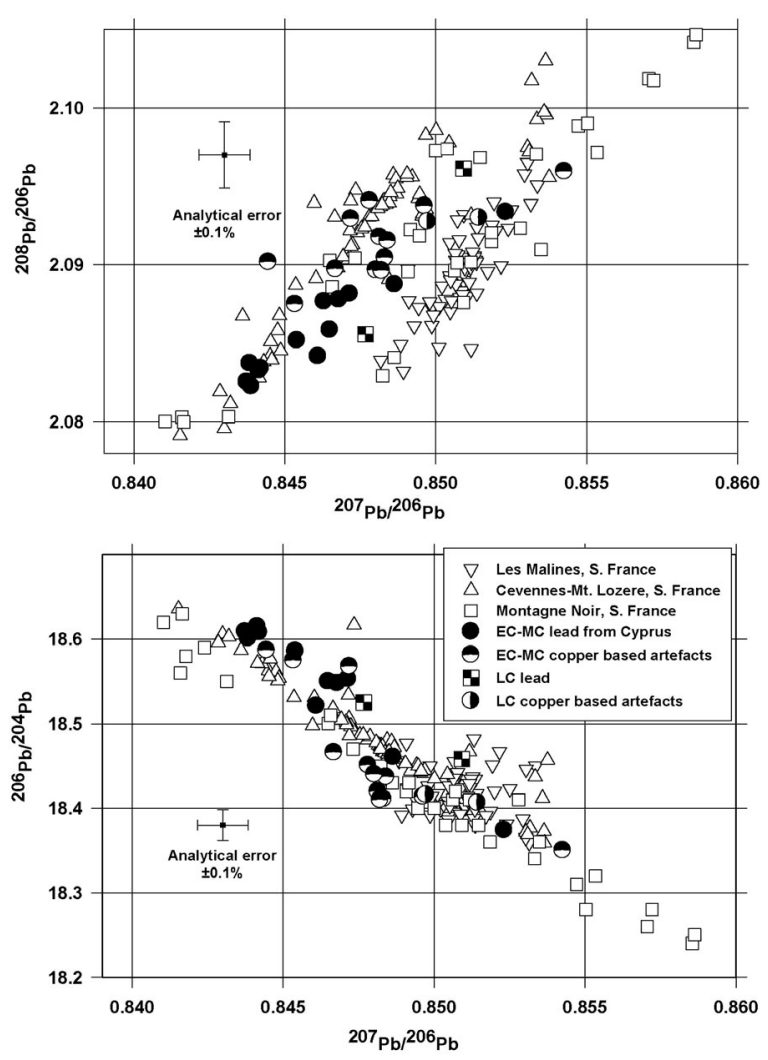

Fig. 3. Two mirror plots of lead isotope ratios of the lead and copper ores from the Massif Central (southern France) and metal artefacts excavated on Bronze Age Cypriot sites from the Group B consistent with the origin from these ores.

bronzes: an axe from Lapithos and a dagger from Kalopsidha. From a later period there is a tin bronze knife from Nitovikla and piece of lead from Maa-Paleokastro. From LC3 (1200-1050 $\mathrm{BC})$ two pieces amongst the metals from Hala Sultan Tekke, a lead "multiple cross" and some fragments of tin bronze are also consistent with the lead isotope composition of ores from the Massif Central.

Perhaps the trade route for these small objects can be traced through parallel finds in the Aegean, Italy and the Adriatic Mediterranean coast? For example, there are two artefacts from Early Bronze Age sites in mainland Greece: a pin from Lerna and a band with rosettes from Lithares, both containing tin, which now can be said to be consistent with the ores from the Massif Central (Kayafa et al. 2000, Tabs. 2.1, 2.2, 2.4 and 2.5, artefacts 33/L5.839 and L7074, pp. 41-46). We have not yet re-ex- 


\begin{tabular}{|c|c|c|c|c|c|}
\hline Region or site & Object & Dated to & ${ }^{208} \mathrm{~Pb} /{ }^{206} \mathrm{~Pb}$ & ${ }^{207} \mathrm{~Pb} /{ }^{206} \mathrm{~Pb}$ & ${ }^{206} \mathrm{~Pb} /{ }^{204} \mathrm{~Pb}$ \\
\hline Ay. Paraskevi & Lead ring AP1 (T8/308) (2) & EC 3-MC1? & 2.09337 & 0.85232 & 18.374 \\
\hline Ay. Paraskevi & Lead ring AP2 (T8/308) (2) & EC 3-MC1? & 2.08779 & 0.84679 & 18.548 \\
\hline Lapithos & Lead ring L-3 (3) & EC 3-MC1 & 2.08767 & 0.84630 & 18.805 \\
\hline Lapithos & Lead ring L-4 (3) & EC 3-MC1 & 2.08518 & 0.84540 & 18.586 \\
\hline Lapithos & Lead ring L-5 (3) & EC 3-MC1 & 2.08876 & 0.84864 & 18.607 \\
\hline Lapithos & Lead ring L-6 (3) & EC 3-MC1 & 2.08418 & 0.84610 & 18.521 \\
\hline Lapithos & Lead ring L-7 (3) & EC 3-MC1 & 2.08327 & 0.84414 & 18.615 \\
\hline Lapithos & Lead ring L-8 (3) & EC 3-MC1 & 2.08255 & 0.84374 & 18.609 \\
\hline Lapithos & Lead ring L-9 (3) & EC 3-MC1 & 2.08373 & 0.84384 & 18.601 \\
\hline Lapithos & Lead ring L-10 (2) & EC 3-MC1 & 2.08342 & 0.84420 & 18.608 \\
\hline Lapithos & Lead ring L-11 (3) & EC 3-MC1 & 2.08586 & 0.84649 & 18.550 \\
\hline Lapithos & Lead ring L-12 (3) & EC 3-MC1 & 2.08817 & 0.84715 & 18.553 \\
\hline Lapithos & Lead ring L-13 (3) & EC 3-MC1 & 2.08226 & 0.84389 & 18.605 \\
\hline Lapithos & Tin bronze awl 313:B86 & EC 3-MC1 & 2.09543 & 0.84917 & 18.439 \\
\hline Lapithos & Tin bronze tweezers 313:A9 & MC1 & 2.09409 & 0.84781 & 18.451 \\
\hline Alambra & Copper ring fragments (3) A 1021 (5) & $\mathrm{MC1}$ & 2.09478 & 0.84872 & 18.440 \\
\hline Alambra & Copper ring fragments (10) A 1027 (5) & $\mathrm{MC1}$ & 2.09491 & 0.8489 & 18.447 \\
\hline Kalopsida & Tin bronze dagger $\mathrm{C} 470(2)$ & MC1-2 & 2.09154 & 0.84841 & 18.437 \\
\hline Kalopsida & Tip of copper dagger C471 (2) & MC1-2 & 2.09294 & 0.84719 & 18.568 \\
\hline Lapithos & Tin bronze axe $315: \mathrm{B}-\mathrm{C} 4$ & MC2? & 2.09595 & 0.85426 & 18.350 \\
\hline Lapithos & Tin bronze pin $316: 167$ & MC2-3 & 2.09018 & 0.84445 & 18.587 \\
\hline Lapithos & Tin bronze pin $316: 175(7)$ & MC2-3 & 2.08967 & 0.84802 & 18.44 \\
\hline Lapithos & Tin bronze pin $320: 98(7)$ & MC2-3 & 2.08963 & 0.84821 & 18.41 \\
\hline Lapithos & Tin bronze pin $316: 173$ & MC2-3 & 2.09376 & 0.84963 & 18.414 \\
\hline Lapithos & Tin bronze pin $702: 128(7)$ & MC3 & 2.08973 & 0.84668 & 18.466 \\
\hline Leondari Vouno tombs & Tin bronze toggle pin 1888.1318 (3) & MC3 & 2.0875 & 0.84534 & 18.575 \\
\hline Nitovikla & Tin bronze knife NIT GR.2.70 & MC3/LC 1 & 2.09276 & 0.84973 & 18.416 \\
\hline Maa-Palaeokastro & Piece of lead 1982:111(3) & LC 2C & 2.09613 & 0.85092 & 18.458 \\
\hline Hala Sultan Tekke & Pieces of tin bronze N6060 (4) & LC $3 \mathrm{~A}$ & 2.09301 & 0.851433 & 18.407 \\
\hline Hala Sultan Tekke & Lead “multiple cross' N1185A (4) & LC $3 \mathrm{~A}$ & 2.08557 & 0.84767 & 18.525 \\
\hline
\end{tabular}

Tab. 4. Artefacts from BA Cypriot sites consistent with origin from the ore deposits in the Massif Central, SE France.

amined all our lead isotope data for Bronze Age metals from sites in the Aegean for overlaps with ores from the Western Mediterranean, but it is not impossible that more such artefacts will be found.

Admittedly, some of the artefacts listed above have lead isotope ratios similar within the analytical error with the copper ores and slags from Huelva analysed at Oxford (Hunt-Ortiz 2003). However, as a group these objects fit better with the lead and copper ores from the Massif Central, and since lead is eminently present in this group of Cypriot finds it is unlikely that it comes from Spain since, as mentioned above, lead was not produced in Spain in the earlier part of the Bronze Age.

(7) Published in Stos-Gale and Gale 1994, pp. 212 and 215.
Another large group of artefacts found on Cypriot sites consisting of 16 pieces of lead and 7 tin bronzes, dated mostly to the $12^{\text {th }}$ and $11^{\text {th }}$ century $\mathrm{BC}$, has lead isotope ratios consistent with the Sardinian ore deposits; the copper for some of them possibly might instead originate from the Huelva or Los Pedroches in Spain (Tab. 5). The Sardinian origin of these metals is not surprising since a number of stylistically Cypriot artefacts was found in the Nuragic settlements, including pottery and a bronze tripod, and therefore it demonstrates the contacts between Cyprus and Sardinia (Lo Schiavo et al. 1985). Additionally, many fragments, and some complete, copper "oxhide" ingots made from copper isotopically consistent with the origin from Cyprus were found on Sardinian LBA sites (Stos-Gale et al. 1997; Gale 1999). If some lead and copper from Sardinia were shipped in the other direction, then by the $11^{\text {th }} \mathrm{c}$. BC copper from Huelva, and possi-

T. P., 67, N. ${ }^{\circ} 2$, julio-diciembre 2010, pp. 389-403, ISSN: 0082-5638

doi: $10.3989 /$ tp.2010.10046 


\begin{tabular}{|c|c|c|c|c|c|}
\hline Region or site & Object & Dated to & ${ }^{208} \mathrm{~Pb} /{ }^{206} \mathrm{~Pb}$ & ${ }^{207} \mathrm{~Pb} /{ }^{206} \mathrm{~Pb}$ & ${ }^{206} \mathrm{~Pb} /{ }^{204} \mathrm{~Pb}$ \\
\hline Pyla Kokkinokremos & Lead cylinder, inscribed 1982:34 (4) & LC $2 \mathrm{C}$ & 2.11998 & 0.87308 & 17.901 \\
\hline Pyla Kokkinokremos & Lead scrap 1982:131 (4) & LC 2C & 2.12761 & 0.87534 & 17.945 \\
\hline Kition & Pointed oblong piece of lead 1975:AR & & & & \\
\hline & $\mathrm{II} / 4301(3)$ & LC $2 \mathrm{C}: 2$ & 2.13113 & 0.87492 & 17.941 \\
\hline Kition & Lead sheet AR I/962 (3) & LC $2 \mathrm{C}-3 \mathrm{~A}$ & 2.12991 & 0.87534 & 17.962 \\
\hline Kition & Lead scrap AR I/962/1 (3) & LC $2 \mathrm{C}-3 \mathrm{~A}$ & 2.12219 & 0.87439 & 17.897 \\
\hline Kition & Lead piece 1972:AR II/3230 (4) & LC 3A & 2.12244 & 0.87407 & 17.892 \\
\hline Hala Sultan Tekke & Piece of tin bronze N6060 (1976) (4) & LC $3 \mathrm{~A}$ & 2.09301 & 0.85143 & 18.406 \\
\hline Hala Sultan Tekke & Piece of tin bronze N6060 B (4) & LC $3 \mathrm{~A}$ & 2.09880 & 0.85739 & 18.275 \\
\hline Hala Sultan Tekke & Tin bronze hinge fragment N1459* (8) & LC 3A & 2.10478 & 0.85879 & 18.242 \\
\hline Hala Sultan Tekke & Tin bronze strip N1328 (8) & LC 3A & 2.10972 & 0.86361 & 18.151 \\
\hline Hala Sultan Tekke & Tin bronze lump F1548* (8) & LC $3 \mathrm{~A}$ & 2.12200 & 0.87111 & 17.996 \\
\hline Hala Sultan Tekke & Lead net weight N1177 A & LC 3A & 2.09265 & 0.85417 & 18.342 \\
\hline Hala Sultan Tekke & Lead piece N1461/5 (4) & LC 3A & 2.12159 & 0.87284 & 17.930 \\
\hline Hala Sultan Tekke & Lead net weight N1168 A (4) & LC 3A & 2.12326 & 0.87418 & 17.896 \\
\hline Hala Sultan Tekke & Lead net weight N1273 (4) & LC $3 \mathrm{~A}$ & 2.12277 & 0.87514 & 17.905 \\
\hline Hala Sultan Tekke & Lead strip N1461/4 (4) & LC 3A & 2.12604 & 0.87477 & 17.913 \\
\hline Hala Sultan Tekke & Lead net weigh N1170 A (4) & LC 3A & 2.12445 & 0.87485 & 17.927 \\
\hline Hala Sultan Tekke & Lead net weight N1273 (4) & LC 3A & 2.12277 & 0.87514 & 17.905 \\
\hline Maa-Palaeokastro & Lead fragment, 1984:249 (3) & LC & 2.12376 & 0.87303 & 18.805 \\
\hline Maa-Palaeokastro & Lead piece 1980:26 (3) & $\mathrm{LC}$ & 2.12508 & 0.87475 & 17.906 \\
\hline Maa-Palaeokastro & Lead fragment, molten sheet 1984:272 (3) & $\mathrm{LC}$ & 2.12025 & 0.87142 & 17.979 \\
\hline Pyla Kokkinokremos & Tin bronze fragments PY81 (3) & $\mathrm{LC}$ & 2.10524 & 0.86325 & 18.126 \\
\hline Nitovikla, Famagusta & Bronze shovel C123* (9) & $\mathrm{LC}$ & 2.10418 & 0.85958 & 18.271 \\
\hline
\end{tabular}

Tab. 5. Artefacts from Cypriot BA sites consistent with the origin from Sardinia, or Spain*.

bly from other metal producing sites in Spain, was almost certainly also circulating in the Western Mediterranean, so it is not impossible that some of this metal ended up on Cyprus.

The lead pieces listed in table 5 are scrap, mostly fishing net weights, a very common use of lead in the Bronze Age Mediterranean. The exception is a lead cylinder with some writing on the surface from Pyla Kokkinokremo and a pointed oblong piece from Kition, both are consistent with the origin from Sardinian lead ores.

More interesting are some of the bronzes: for example the lead isotope composition of the shovel C123 from Nitovikla near Famagusta is identical within the analytical error of $\pm 0.1 \%$ with the ores from Monte Romero in Huelva (Spain) published by Hunt (2003, pp. 113-114). The tin bronze hinge fragment from Hala Sultan Tekke has lead isotope ratios that could indicate either Sardinian or Spanish ores. Unfortunately at present it is not possible to decide on the basis of their lead isotope composition alone if this two

(8) Published in Stos-Gale and Gale 1994, pp. 214 and 216.

(9) Published in Stos-Gale and Gale 1994, pp. 213, also mistakenly listed as C128 on p. 214. objects were made of metal from Sardinia or from Spain.

\section{CONCLUSIONS}

Standardised lead isotope data obtained by TIMS or ICP-MC-MS provide immutable characteristics of ancient metal artefacts which can allow the identification of the ore deposits from which the metals came. As long as the data has been collected with good accuracy (which for these two techniques is usually well attested), the interpretation of the origin of ancient material can be updated periodically by comparisons with newly published lead isotope data for ores. The results are not always unambiguous. For example, while there is really no problem with overlaps of lead isotope compositions of the Aegean, Turkish and Cypriot ore deposits with any other copper, lead and silver occurrences, in the Western Mediterranean, some ores from Spain and Sardinia do have mutually similar ranges of lead isotope compositions. However, this does not always mean that for the artefact data falling in this 
region there is no possibility of identifying the origin of the metal. Each case needs to be carefully considered in view of the history of mining, geochemistry of the ores and elemental analyses of artefacts. Usually such a holistic approach gives a good indication of the real source of the metal.

The current re-evaluation of the origin of metals from Bronze Age sites on Cyprus shows that there is an interesting group of metals, mainly from the tombs in Lapithos, dated to the beginning of the $2^{\text {nd }}$ millennium $\mathrm{BC}$ that are consistent with an origin from the lead, copper and silver deposits in the Massif Central. Some of these objects are made from tin bronze. These results need to be compared with the isotopic and elemental composition of metals excavated from Bronze Age sites in the South of France to give them full credibility.

Amongst the artefacts dated to the end of the $2^{\text {nd }}$ millennium BC many lead pieces are consistent with an origin from the Cambrian Sardinian lead ore deposits. A few of the tin bronzes have lead isotope ratios that suggest the origin of their copper metal from Spanish mines. Further re-evaluation of lead isotope data on the OXALID database are planned to identify other metal artefacts in the Eastern Mediterranean that might have been made from metal traded from the West.

\section{REFERENCES}

Ambert, P. 1995: "Les mines Préhistoriques de Cabrières (Herault): Quinze ans de recherches, état de la question". Bulletin de la Société Préhistorique Française 92/4: 499-508.

Baron, S.; Carignan, J.; Laurent, S. and Ploquin, A. 2006: "Medieval lead making on Mont-Lozere Massif (Cevennes-France): Tracing ore sources using $\mathrm{Pb}$ isotopes". Applied Geochemistry 21, 241-252.

Bass, G.F. 1987: "Oldest known shipwreck reveals splendors of the Bronze Age". National Geographic, 172/6. 693-734.

Begemann, F.; Schmitt-Strecker, S.; Pernicka, E. and Lo Schiavo, F. 2001: "Chemical Composition and Lead Isotopy of Copper and Bronze from Nuragic Sardinia". European Journal of Archaeology 4 (1): 43-85.

Brevart, O.; Dupre, B. and Allegre, C.J. 1982: "Metallogenic provinces and the remobilisation process studies by lead isotopes; lead-zinc ore deposits from the southern Massif Central, France". Economic Geology 77/3: 564-575.

Delibes, G. and Montero, I. (coord.) 1999: Las primeras etapas metalúrgicas en la Península Ibérica. II: Estudios regionales. Instituto Universitario Ortega y Gasset. Madrid.

Gale, N.H. 1999. "Characterization by lead isotopes and trace elements of the ore deposits of Cyprus and Sardinia in the light of current theories of their metallogenesis, and its bearing on the possibility of the lead isotope provenancing of copper alloys" - in the Proceedings of the Symposium Metals in Antiquity, Harvard 1997, eds. S. Young, M. Pollard, P. Budd, and R.A. Ixer, BAR Int. Series 792, Archaeopress, Oxford, 110-121.

Gale, N.H. and Stos-Gale, Z.A. 1981: "Cycladic lead and silver metallurgy". Annual of the British School at Athens, 76, 169-224.

Gale, N.H.; Stos-Gale, Z.A.; Maliotis, G. and Annetts, N. 1997a: "Lead isotope data from the Isotrace Laboratory, Oxford: Archaeometry data base 4, ores from Cyprus". Archaeometry 39 (1): 237-246.

Gale, N.H.; Stos-Gale, Z.A. and Fasnacht, W. 1997b: "Movable finds: metal and metalworking in Alambra, a Middle Bronze Age site in Cyprus". In J.E. Coleman, J.A. Barlow, M.K. Mogelonsky and K.W. Schaar (eds.): Investigations by Cornell University 1974-1985. 129-41 and 371-438.

Gale, N.H. and Stos-Gale, Z.A. 2005: "Zur Herkunft der Kupferbarren aus dem Schiffswrack von Uluburun und der spätbronzezeitliche Metallhandel im Mittelmeerraum". In U. Yalcin, C. Pulak and R. Slota (eds.): Das Schiff von Uluburun - Welthandel vor 3000 Jahren. Bochum. 117-132.

Gale, N.H. and Stos-Gale, Z.A. 2008a: "Changing Patterns in Prehistoric Cycladic Metallurgy". In N. Brodie, J. Doole, G. Gavalas and C. Renfrew (eds.): Horizon: A Colloquium on the Prehistory of the Cyclades, McDonald Institute for Archaeological Research, Cambridge, 387-408.

Gale, N.H.; Kayafa, M. and Stos-Gale, Z.A. 2008b: "Early Helladic Metallurgy at Raphina, Attica, and the Role of Lavrion". In I. Tzachili (ed.): Aegean Metallurgy in the Bronze Age, University of Crete, Rethymnon, 87-104.

Gale, N.H.; Kayafa, M. and Stos-Gale, Z.A. 2009: "Further evidence for Bronze Age production of copper from ores in the Lavrion ore district, Attica, Greece". In Proceedings of the $2^{\text {nd }}$. International Conference Archaeometallurgy in Europe, Aquileia, 2007, AIM Milan, 158-176.

Giardino, C. 1992: "Nuragic Sardinia and the Mediterranean Metallurgy and Maritime Traffic". In R.H. Tykot and T.K. Andrews (eds.): Sardinia in the Mediterranean: A footprint in the sea. Studies in Sardinian Archaeology presented to Miriam Bal- 
muth. Sheffield Academic Press, Sheffield. 304-316.

Giardino, C. 2000: "Sicilian hoards and Protohistoric metal trade in the Central West Mediterranean". In C.F.E. Pare (ed.): Metals make the world go round the supply and circulation of metals in Bronze Age. Proceedings of a conference held at the University of Birmingham, June 1997. Oxbow Books, Oxford. 99-107.

Gurthez, X.; Jallot, L. and Bordreuil, M. 2005: “Age du cuivre et changemenst sociaux en Languedoc méditerranéen". En P. Ambert y J. Vaquer (dir.): $L a$ première métallurgie en France et dans les pays limitrophes. Carcassonne, 28-30 Septembre 2002: Actes du colloque international. Mémoire XXXVII, Société Préhistorique Française: 119-130.

Hauptmann, A.; Begemann, F.; Heitkemper, R.; Pernicka, E. and Schmitt-Strecker, S. 1992: "Early copper produced in Feinan, Wadi Araba, Jordan: the composition of ores and copper". Archeomaterials 6 (1): 1-33.

Heyd, V. 2007: "When the West meets the East: the eastern periphery of the Bell Beaker phenomenon and its relation with the Aegean Early Bronze Age". In: I. Galanaki, H. Tomas, Y. Galanakis and R. Laffineur (eds.): Between the Aegean and Baltic Seas - Prehistory across borders. Proceedings of the International Conference and Early iron Age Interconnections and Contemporary Developments between Aegean and the regions of the Balkan Peninsula, central and Northern Europe, University of Zagreb (11-14 April 2005). Aegeum 27, Universite de Liege et UT-PASP. 91-103 P1. XIX-XXI.

Hirao, Y.; Enomoto, J. and Tachikawa, H. 1995: "Lead isotope ratios of copper, zinc and lead minerals in Turkey in relation to the provenance study of artefacts". In H.I.H. Prince Takahito Mikasa (ed.): Essays on Ancient Anatolia and its surrounding civilisations. Harrassovitz Verlag, Wiesbaden. 89-114.

Hunt-Ortiz, M.A. 2003: Prehistoric Mining and Metallurgy in South-West Iberian Peninsula. BAR International Series 1188.

Karageorghis, V.; Gale, N.H. and Stos-Gale, Z.A. 1983: "Two silver ingots from Cyprus". Antiquity LVII 211-214.

Kassianidou, V. 2001: “Cypriot copper to Sardinia. Yet another case of bringing coasl to Newcastle?". In Larisa Bonfante and Vassos Karageorghis (eds.): Italy and Cyprus in Antiquity: 1500 - 450 BC. Proceedings of an International Symposium held at the Italian Academy for Advanced Studies in America at Columbia University, November 16 - 18, 2000. The Costakis and Leto Severis Foundation. Nicosia. $97-120$.

Kayafa, M.; Stos-Gale, Z.A. and Gale, N.H. 2000: "The circulation of copper in the Early Bronze Age in Mainland Greece: the lead isotope evidence from Lerna, Lithares and Tsoungiza". Metals make the world go round: supply and circulation of metals in Bronze Age Europe. Ed. C. Pare. Oxbow Books, Oxford. 39-55.

Klein, S.; Domergue, C.; Lahaye, Y.; Brey, G.P. and Von LKaenel, H.-M. 2009: "The lead and copper isotopic composition of copper ores from the Sierra Morena (Spain)". Journal of Iberian Geology 35 (1): 59-68.

Le Guen, M.; Orgeval, J.-J. and Lancelot, J. 1991: "Lead isotope behaviour in a polyphased $\mathrm{Pb}-\mathrm{Zn}$ ore deposit: Les Malines (Cevennes, France)". Mineral Deposits 26: 180-188.

Lo Schiavo, F.; Macnamara, E. and Vagnetti, L. 1985: "Late Cypriot imports to Italy and their influence on local Bronzework". Papers of the British School at Rome 53: 1-70.

Maran, J. 2007: "Seaborne contacts between the Aegean, the Balkans and the central Mediterranean in the $3^{\text {rd }}$ Millennium BC. The unfolding of the Mediterranean World". In I. Galanaki, H. Tomas, Y. Galanakis and R. Laffineur (eds.): Between the Aegean and Baltic Seas - Prehistory across borders. Proceedings of the International Conference and Early iron Age Interconnections and Contemporary Developments between Aegean and the regions of the Balkan Peninsula, Central and Northern Europe, University of Zagreb (11-14 April 2005). Aegeum 27, Universite de Liege et Ut-Pasp. $3-24$.

Montero-Ruiz, I.; Castanyer, P.; Gener, M.; Hunt, M.; Mata, J.M.; Pons, H.; Rovira-Llorens, S.; Rovira-Hortala, C.; Renzi, M.; Santos-Retolaza, M. and Santos-Zalduegui, J.F. 2009a: Lead and silver metallurgy in Emporion (L'Escala, Girona, Spain). Proceedings of the $2^{\text {nd }}$ International Conference on Archeometallurgy in Europe, Aquileia, Italy 2007. Available on CD ROM.

Montero-Ruiz, I.; Gener, M.; Renzi, M.; Hunt, M.; Rovira, S. and Santos-Zalduegui, J.F. 2009b: "Provenance of elad in first Iron Age sites in Southern catalonia (Spain)". Proceedings ISA 2006. Eds. J.F. Moreau, R. Auger, J. Chabot and A. Herzog. Quebec. 391-398.

Muhly, J.D. 1991: "The development of copper metallurgy in Late Bronze Age Cyprus". In N.H. Gale (ed.): Bronze Age Trade in the Mediterranean, SIMA XC, Paul Åströms Forlag, 180-196.

Pernicka, E.; Seeliger, T.C.; Wagner, G.A.; Begemann, F.; Schmitt-Strecker, S.; Eibner, C.; Õztunali, Õ. and Baranyi, I. 1984: "Archäometallurgische Untersuchungen in Nordwestanatolien", Jahrbuch des Römisch-Germanischen Zentralmuseums 31: 533-99.

Pernicka, E.; Begemann, F.; Schmitt-Strecker, S. and Wagner, G.A. 1993: "Eneolithic and Early Bronze

T. P., 67, N. ${ }^{\circ}$ 2, julio-diciembre 2010, pp. 389-403, ISSN: 0082-5638 doi: $10.3989 /$ tp.2010.10046 
Age copper artefacts from the Balkans and their relation to Serbian copper ores". Praehistorisches Zeitschrift 68 (1): 1-54.

Pulak, C. 1998: "The Uluburun Shipwreck: An Overview". International Journal of Nautical Archaeology 27: 188-224.

Pulak, C. 2001: "The cargo of the Uluburun ship and evidence for trade with the Aegean and beyond". In L. Bonfante and V. Karageorghis (eds.): Italy and Cyprus in Antiquity: 1500-450 BC. Proceedings of an International Symposium held at the Italian Academy for Advanced Studies in America at Columbia University (November 16-18, 2000). The Costakis and Leto Severis Foundation. Nicosia. 13-60.

Pulak, C. 2005: "Das Schiffswrack von Uluburun". In U. Yalcin, C. Pulak and R. Slota (eds.): Das Schiff von Uluburun - Welthandel vor 3000 Jahren. Katalog der Ausstellung des Deutschen Bergbau-Museums Bochum vom 15-16 Juli 2006. Bochum. 55-102.

Renzi, M.; Montero-Ruiz, I. and Bode, M. 2009: "Non-ferrous metallurgy from the Phoenician site of La Fonteta (Alicante, Spain) a study of provenance". Journal of Archaeological Science 36: 2584-2596.

Santos Zaldeuegui, J.F.; García de Madinabeitia, S.; Gil Ibarguchi, J.I. and Palero, F. 2004: "A lead isotope database: the Los Pedroches Alcudia area (Spain); implications for archaeometallurgical connections across south western and south eastern Iberia". Archaeometry 46 (4): 625-634.

Seeliger, T.C.; Pernicka, E.; Wagner, G.A.; Begemann, F.; Schmitt-Strecker, S.F.; Eibner, C.; Öztunali, Ö. and Baranyi, I. 1985: "Archaeometallurgische Untersuchungen in Nord- und Ostanatolien". Jahrbuch des Romisch-Germanischen Zentralmuseums Mainz 32: 597-659.

Skaggs, S.A. 2009: Lead Isotope Analysis of Roman Carthage Curse Tablets in Archaeological Chemistry: Analytical Techniques and Archaeological Interpretation. Edited by M.D. Glascock, R.J. Speakman and R.S. Popelka-Filcoff. American Chemical Society: Washington, D.C.

Stacey, J.S.; Doe, B.R.; Roberts R.J.; Delevaux M.H. and Gramlich, J.W. 1980: "A Lead Isotope Study of Mineralization in the Saudi Arabian Shield". Contributions to Mineralogy and Petrology 74: 175-188.

Stos, Z.A. 2009: "Across the wine dark seas. Sailor tinkers and royal cargoes in the Late Bronze Age eastern Mediterranean". In A.J. Shortland, I.C. Freestone and T. Rehren (eds.): From Mine to Microscope - Advances in the Study of Ancient technology. Oxbow Books, Oxford. ISBN 9781 184217259 9.163-180.
Stos-Gale, Z.A. 2000: "Trade in Metals in the Bronze Age Mediterranean: an overview of Lead Isotope Data for provenance studies". Metals make the world go round: supply and circulation of metals in Bronze Age Europe. Ed. C. Pare. Oxbow Books, Oxford. 56-69.

Stos-Gale, Z.A. and Gale, N.H. 1980: "Sources of galena, lead and silver in Predynastic Egypt". Actes du XXeme Symposium International d'Archeometrie. Revue d'Archeometrie 5/III: 285-295.

Stos-Gale, Z.A. and Gale, N.H. 1992: "New light on the provenance of the copper oxhide ingots found on Sardinia". Sardinia in the Mediterranean: a Footprint in the Sea. Studies in Sardinian Archaeology presented to Miriam Balmuth. R.H. Tycot and T.K. Andrews (eds.). Sheffield Academic Press. 317-346.

Stos-Gale, Z.A. and Gale, N.H. 1994: "The origin of metals excavated on Cyprus". Chapter 3 in B. Knapp and J. Cherry, eds. Provenance studies and Bronze Age Cyprus: Production exchange and Politico-Economic change. Prehistory Press, Madison. 92-122 and 210-216.

Stos-Gale, Z.A.; Gale, N.H.; Houghton, J. and Speakman, R. 1995: "Lead isotope analyses of ores from the Western Mediterranean". Archaeometry 37 (2): 407-415.

Stos-Gale, Z.A.; Gale, N.H. and Annetts, N. 1996: "Lead isotope analyses of ores from the Aegean". Archaeometry 38 (2): 381-390.

Stos-Gale, Z.A.; Maliotis, G.; Gale, N.H. and Annetts, N. 1997: "Lead isotope characteristics of the Cyprus copper ore deposits applied to provenance studies of copper oxhide ingots". Archaeometry 39 (1): 83-124.

Stos-Gale, Z.A.; Gale, N.H.; Annetts, N.; Todorov, T.; Lilov, P.; Raduncheva, A. and Panayotov, I. 1998a: "Lead isotope data from the Isotrace Laboratory, Oxford: Archaeometry Database 5, Ores from Bulgaria". Archaeometry 40 (1): 217-226.

Stos-Gale, S.; Maliotis, G. and Gale, N.H. 1998b: “A preliminary survey of the Cypriot slag heaps and their contribution to the reconstruction of copper production on Cyprus". In T. Rehren, A. Hauptmann and J. Muhly (eds.): Metallurgica Antiqua, in Honour of Hans-Gert Bachmann and Robert Maddin. Deutches Bergbau Museum, Bochum. 235262.

Stos-Gale, Z.A. and Gale, N.H. 2009: "Metal provenancing using isotopes and the Oxford archaeological lead isotope database (OXALID)". Archaeological and Anthropological Sciences, Springer Berlin/Heidelberg. 1 (3): 195-213.

Wagner, G.A.; Pernicka, E.; Seeliger, T.C.; Oztunali, O.; Baranyi, I.; Begemann, F. and Schmitt-Strecker, S. 1985: "Geologische Unterschungen zur frûhen Metallurgie in NW-Anatolien”. Bulletin of 
the Mineral Research and Exploration Institute of Turkey. 101/102: 45-81.

Wagner, G.A.; Pernicka, E.; Seeliger, T.; Lorentz. I.B.; Begemann, F.; Schmitt-Strecker, S.F.; Eibner, C. and Oztunali, O. 1986a: "Geochemische und isotopische Characteristika früher Rohstoffquellen fur Kupfer, Blei, Silber und Gold in der Turkei". Jahrbuch des Römisch-Germanischen Zentralmuseums Mainz 33: 723-752.

Wagner, G.A.; Pernicka, E.; Vavelidis, M.; Baranyi, I. and Bassiakos, Y. 1986b: "Archaeometallurgische Untersuchungen auf Chalkidiki”. Der Anschnitt 38 Heft 5-6. 166-186.

Wagner, G.A.; Begemann, F.; Eibner, C.; Lutz, J.; Oztunali, O.; Pernicka, E. and Schmitt-Strecker,
S.F. 1989: “Archäometallurgische Untersuchungen an Rohstoffquellen des frühen Kupfers Ostanatoliens". Jahrbuch des Römisch-Germanischen Zentralmuseums Mainz 36: 637-686.

Webb, J.M.; Frankel, D.; Stos, Z.A. and Gale, N.H. 2006: "Early Bronze Age metal trade in the Eastern Mediterranean. New compositional and lead isotope evidence from Cyprus". Oxford Journal of Archaeology 25(3): 261-88.

Yener, K.A.; Sayre, E.V.; Özbal, H.; Joel, E.C.; Barnes, I.L. and Brill, R.H. 1991: "Stable lead isotope studies of Central Taurus ore sources and related artefacts from Eastern Mediterranean Chalcolithic and Bronze Age sites". Journal of Archaeological Science 18(5): 541-577. 